disparaissent pas du jour au lendemain du paysage littéraire, et ce qu'on constate, c'est finalement moins l'apparition de tel ou tel texte que le recyclage continu d'une même matière. Ovide, Boccace ou Marguerite de Navarre semblent être des réservoirs sans fin.

Bref, ce Répertoire fait bien plus que de rendre aisément disponible le contenu de certains ouvrages peu accessibles. En remettant sur le métier, de la façon la plus simple qui soit, l'histoire littéraire, il permet au lecteur de se constituer son propre panorama et lui donne tout bonnement envie d'aller lire ces ouvrages oubliés.

STÉPHAN GEONGET, Université François-Rabelais, Tours

\title{
Pirates? The Politics of Plunder, 1550-1650
}

Edited by Claire Jowitt. Early Modern Literature in History

Basingstoke, Hampshire and New York: Palgrave Macmillan, 2007. Pp. xiii, 244.

This volume, originating in an academic conference, contains ten chapters and an introduction emphasizing the "permeable boundary between legitimate and illegitimate seaborne activities.” This permeability stems from royal authorization of subjects to take reprisals on foreign shipping through "letters of Marque." One result was that diplomatic conventions were depreciated by privateers who, in the face of inadequate state regulation, adopted piratical roles. Claiming wide geographical and interdisciplinary scope, the editor holds that historiographical and literary images of pirates contributed to colonial discourses that justified empire building between 1550 and 1650 . In that period, piracy "intersects with a variety of larger cultural issues: legal, national, colonial, and those to do with race, religion, and gender."

In his chapter, Christopher Harding gives a legal perspective on the "ambivalent view of piratical activity," contrasting it to the "much more definite criminalization of piracy at the turn of the eighteenth century." The earlier period had pragmatic, not moral, reasons for condemning piracy. Hence, Francis Drake and Walter Ralegh were treated as heroes and criminals. Since before 1700 England had limited naval forces, pirates and colonists often co-existed: they mutually benefitted from smuggling and evading commercial rules. While the navy remained small, piracy could be an instrument of state power; but when the state monopolized naval force, piracy had to be eliminated.

John Appleby describes a formative stage in the development of English piracy in the Caribbean and North America: the spread of buccaneers from south-west England to the coast of south-west Ireland. There, out of the reach of English power, 
pirates behaved like the rebels they were regarded as being in the reign of James I, their remoteness defying propaganda about national unity and civilization. Highly organized interlopers in Atlantic trade, they were a boon to the local economy.

To confute aspects of Linda Colley's Captives (2002), a study of English slaves in the Ottoman empire, Nabil Matar draws on North African captivity narratives. His innovative research shows that Islamic narratives, despite Muslim conventions of self-effacement, evidence persistent raids by European nations into the Maghrib for slaves. Spanish and Portuguese pirates sold Muslim slaves across Europe. Dealing with "subtexts in texts," Matar reminds us that Islam upholds a theology not of personal suffering and redemption but of "submission to Allah." Hence, the trope of the Muslim slave emphasized endurance and the defiance of infidelity. While not comparing his evidence to the narrative genre of European slaves in Barbary, Matar suggests that Christian converts to Islam familiarized the Maghribi with European values.

The next four chapters probe ideological conflicts in European values. Matthew Dimmock discusses the sectarian propaganda by which the English demonized the King of Spain in the early 1590s, showing how official proclamations threatened to implode given the ambiguous nature of piracy. Fear of another armada led English Protestants to assert their identity in the form of an "apocalyptic endgame": God's elect must be victorious. As films such as The Sea Hawk (1941) claim, renegade Catholic Englishmen worked for Spain with ideologies that presented Protestants as Turks. Mark Hutchings considers Turkish motifs in the English imaginary of the 1580 s and 1590s, basing his chapter on Robert Daborne's play, A Christian Turned Turk (1610-11). Despite James I's opposition to piracy, it flourished in the Mediterranean "in the wake of the Levant Company's success." John Ward, the play's protagonist, is a pirate who converts to Islam. Condemned in the play, he lived to a ripe age at Tunis. For Hutchings, the doubling of players' roles undermines the play's condemnation of piratical apostasy by associating merchants with pirates. The play endorses what it would deny, implying the fluidity of social and national identity. Hunting out implications like Matar, Bernhard Klein reads The Lusiads (1572) for evidence that piracy is an imaginative constituent of this Portuguese maritime epic. Following Marcus Rediker, Klein shows that the poem makes unhistorical claims for Vasco Da Gama's heroism. No discoverer, Da Gama exploited long established trading routes in the Indian Ocean and local pilots. The Portuguese introduced armed domination of trading routes, making $\mathrm{Da}$ Gama best seen as a pirate. That the poem attempts to preclude piracy exposes its defensive concern for national heroism. Below the story of Da Gama's navigational skills lies reluctant acknowledgment 
of “compromise and negotiation." Lucy Munro's chapter on gender and genre in Fletcher and Massinger's The Double Marriage argues that Martia, the character with the chief capacity for amoral political disruption, is an Amazon whose piracy is punished beyond her deserts.

The volume's final three chapters consider the "afterlife" of Renaissance piracy. Mark Netzloff argues that, whereas Drake became a myth to the Victorians, he was a spectral figure in the creative writing of his own time. Only minor writers associated with the urban mercantile classes, who saw Drake as a model for their maritime ventures, dealt with his commercial piracy. Claire Jowitt's chapter focussing on the discontinuous ways in which the Elizabethan and Jacobean states treated pirates examines the political inconsistencies and arbitrary justice involved in their executions. Gerald MacLean surveys war-mongering poetry following American Independence to challenge the UsA's claim to be historically exceptional. Easy expectations about conquering the corsairs are paralleled to today's imperial illusions, Maclean finding in a poem by a Boston-born lawyer, David Humphreys, militaristic "disinformation."

A strong point in this miscellaneous volume is that its chapters refer to one another. Although well documented and amply annotated, it is at times held together by little more than simple anti-imperialism. Its exposition and argumentation are uneven, and the editing might have been much stronger given the typographical and grammatical errors.

ROBERT JAMES MERRETT, University of Alberta

\section{Michael S. Springer}

\section{Restoring Christ's Church: John a Lasco and the Forma ac ratio}

St. Andrews studies in Reformation history. Aldershot: Ashgate, 2007. Pp. ix, 177.

In recent years there has been a quiet resurgence of interest in the Polish nobleman and reformer Jan Łaski or John a Lasco (1499-1560). Lasco has emerged from the shadows and now must be considered with Calvin and Bullinger as one of the three major figures of the Reformed tradition. Indeed it can be argued that in the latter stages of his career he was even more influential than Calvin himself in shaping the contours of the Reformed church on an international level. Lasco was certainly the most well travelled of the three. He never lived more than five years in a single place as his career took him from London to Vilnius with many stops in between. From a privileged background of power and wealth, Lasco was accustomed to lead, and 